\title{
WUJUD KEBUDAYAAN JAWA DALAM BENTUK RUMAH LIMASAN
}

\author{
Kristiana Rizqi Rohmah \\ IAIN Ponorogo Jawa Timur \\ kristijutek89@gmail.com
}

\begin{abstract}
This research discusses the limas house of Javanese society. One of the Javanese traditional houses. The purpose of this research is to describe the Javanese people's view of life towards the limasan house shape, to describe the Javanese norms towards the limasan house shape, to describe the harmonization principle of Javanese society towards the limasan house shape, to describe the Javanese people's respect for the limasan house shape, to describe the physical dimensions. Javanese society towards the shape of the limasan house, describes the metaphysical dimension of the Javanese society towards the shape of the limasan house. The research method uses descriptive qualitative research with data collection techniques in the form of observation. The results of the research on the Limasan traditional house building based on the Javanese view of life based on their beliefs can be seen from the Javanese house buildings in the Yogyakarta and Surakarta areas which are close to the Keraton that the house building faces south based on the location of Ratu Nyai Roro Kidul. Based on the duality and centrality category of Javanese house buildings. Based on the religious norms adopted by the Javanese, the house buildings are more similar to the Hindu religious buildings, although not all Javanese people embrace the Hindu and Buddhist religions. The form of the building which is simple and has similarities between one house and another is a symbol that the Javanese people uphold the value of harmony. The construction of the Limasan house is based on the principle of respect for the Javanese people which is shown from the front of the house which is commonly called the emper. The empire in the limasan house is made shorter than the first inner building of the limasan house. The simple personality of the people can be seen clearly from the limasan house building. Each part of the house has a metaphysical value which is believed to be the true meaning of the part of the limasan house.
\end{abstract}

Keywords: Limas house, Java, culture.

\section{Latar Belakang Masalah}

Kebudayaan atau budaya menyangkut keseluruhan aspek kehidupan manusia baik materiel maupun nonmaterial (Setiadi, dkk, 2014:28). Menurut Koentjaraningrat dalam 
Setiadi, dkk (2014:28) kebudayaan adalah keseluruhan sistem gagasan, milik diri manusia dengan belajar. Soemardjan dan Soemardi dalam Setiadi, dkk (2014:28) mengatakan bahwa kebudayaan adalah semua hasil karya, rasa, dan cipta masyarakat. Kebudayaan dalam hal ini menyangkut hasil karya manusia yang dihubungkan dengan kehidupannya.

Kebudayaan Jawa memiliki beragam jenis, salah satunya rumah adat. Rumah adat masyarakat Jawa memiliki berbagai macam jenis. Beberapa macam jenis tersebut menunjukkan bahwa masyarakat Jawa memiliki keragaman budaya. Budaya Jawa tersebut tidak hanya rumah adat, antara lain bahasa, pakaian adat, upacara, dan alat tradisional. Berbagai macam kebudayaan tersebut berhubungan dengan kepribadian masyarakat Jawa. Beberapa prinsip hidup masyarakat Jawa memengaruhi adanya kebudayaan ini.

Rumah adat Jawa yang beragam tersebut memiliki nilai masing-masing. Nilai yang paling kuat dan paling lengkap mencerminkan masyarakat Jawa adalah rumah Joglo. Rumah Joglo biasanya terdapat pada bangunan keraton. Keraton yang memiliki konsep rumah Joglo memiliki nilai metafisik yang beragam. Ornamen-ornamen yang terdapat didalamnya juga menunjukkan adanya harmonisasi masyarakat Jawa. Ornamen tersebut tidak hanya digunakan sebagai hiasan tetapi juga digunakan untuk rirual keagamaan.

Bangunan pada rumah adat limasan lebih sederhana dari rumah joglo. Rumah limasan memiliki ruang yang hanya terdiri dari rumah dalem (emper, ruang tengah yang dibiarkan kosong dan senthong). Rumah limasan merupakan rumah yang sampai sekarang masih banyak digunakan sebagai model rumah masyarakat Jawa di pedesaan. Masyarakat Jawa memilih rumah limasan sebagai desain rumahnya dengan desain yang paling sederhana. Desain rumah tersebut tidak memiliki ornamen yang banyak dan memiliki kesan mewah. Ornamen yang digunakan benar-benar disesuaikan dengan konsep rumah limasan yang lebih sederhana dari rumah joglo. Berbagai konsep ruang dalam rumah limasan menunjukkan kepribadian masyarakat Jawa di pedesaan yang memiliki kepribadian lebih sederhana daripada masyarakat Jawa yang tinggal di kota. 


\section{Landasan Teori}

\section{Kebudayaan}

Kebudayaan atau budaya menyangkut keseluruhan aspek kehidupan manusia baik materiel maupun nonmaterial (Setiadi, dkk, 2014:28). Menurut Koentjaraningrat dalam Setiadi, dkk (2014:28) kebudayaan adalah keseluruhan sistem gagasan, milik diri manusia dengan belajar. Soemardjan dan Soemardi dalam Setiadi, dkk (2014:28) mengatakan bahwa kebudayaan adalah semua hasil karya, rasa, dan cipta masyarakat.

Berdasarkan beberapa pendapat tersebut dapat disimpulkan bahwa kebudayaan adalah semua hasil karya yang menyangkut kehidupan manusia baik materiel maupun non materiel.

\section{Kebudayaan Jawa}

Daerah kebudayaan Jawa itu luas, yaitu meliputi seluruh bagian tengah dan timur dari pulau Jawa. Sungguhpun demikian ada daerah-daerah yang secara kolektip serig disebut daerah Kejawen. Sebelum terjadi perobahan-perobahan status wilayah seperti sekarang ini, daerah itu ialah Banyumas, Kedu, Yogyakarta, Surakarta, Madiun, Malang dan Kediri. Daerah di luar itu dinamakan Pesisir atau Ujung Timur. Sehubungan dengan hal itu, maka dalam seluruh rangka kebudayaan Jawa ini, dua daerah bekas kerajaan Mataram sebelum terpecah pada tahun 1755, yaitu Yogyakarta dan Surakarta, adalah merupakan pusat dari kebudayaan tersebut (Koentjoroningrat, 1976: 322).

Daerah tempat kediaman orang Jawa ini terdapat berbagai istilah teknis, dialek bahasa, dan lain-lain. Sungguhpun demikian variasi-variasi dan rumah adat Jawaperbedaan tersebut tidaklah besar karena apabila diteliti hal-hal itu masih menunjukkan satu pola ataupun satu sistem kebudayaan Jawa. Sama halnya dengan daerah-daerah kejawen lainnya, di dalam wilayah Daerah istimewa Yogyakarta selatan terdapat kelompok-kelompok masyarakat orang Jawa yang masih mengikuti atau mendukung kebudayaan Jawa ini. Pada umumnya mereka itu membentuk satu kesatuan hidup setempat yang menetap di desa-desa (Koentjoroningrat, 1976: 322). 


\section{Rumah adat Jawa}

Koentjoroningrat (1974: 324) berpendapat bahwa ada beberapa macam rumah berdasarkan bahan dan bentuknya. Ada rumah yang dibangun memakai kerangka dari bambu glugu (batang pohon nyiur) atau kayu jati; kemudian dinding-dindingnya dibuat dari gedek (anyaman belahan bambu), papan atau tembok dan atapnya berupa anyaman daun kelapa kering (blarak), atau dari genting. Sungguhpun demikian rumah tersebut didirikan menurut sistem kerangka tertentu, sehingga membentuk sebuah bangunan persegi. Bagian dalam rumah itu, dibagi-bagi menjadi ruanganruangan kecil yang satu sama lain dipisah-pisahkan dengan gedek yang dapat digeser atau dipindahkan, dan pintunya ialah pintu seret, sedangkan jendela-jendela tidak ada. Sinar matahari dapat masuk melalui lubang dari atas atap dan celah-celah dindingnya (Djono, 2012).

Adapun mengenai bentuk rumah itu yang ditentukan oleh bangun atapnya, ada yang dinamakan rumah limasan, rumah serotong, rumah joglo, rumah panggangepe, rumah daragepak, rumah macan njerum, rumah klabang nyander, rumah tajuk, rumah kutuk ngambang, dan rumah sinom. Dari sekian macam bentuk rumah tersebut rumah limasan adalah yang paling sering ditemui dan menjadi tempat kediaman keturunan penetap desa pertama, di samping rumah serotong. Adapun rumah joglo adalah prototipe rumah bangsawan. Untuk sekarang ini sudah banyak orang yang membuat rumah dengan memakai bahan bangunan yang sepadan dengan rumahrumah orang di kota-kota besar dan gaya atap suatu rumah itu sering menjadi tanda gengsi dan kedudukan sosial (Koentjoroningrat, 1974:325).

Menurut Tjahjono dalam Supriyanto (2002: 12), jenis ruang pada rumah tradisional Jawa yang lengkap terdiri atas Pendopo(ruang pertemuan), Pringgitan (ruang pertunjukan) dan Dalem (ruang inti keluarga). Pada rumah Kampung atau limasan umumnya tidak memiliki pendapa dan pringgitan, sehingga rumah terdiri atas dalem saja. Dalem terdiri atas emperan, bagian tengah yang dibiarkan kosong dan senthong . Senthong terdiri atas Senthong Kiwo, Senthong Tengen dan Senthong Tengah . 
Dalem merupakan bagian terpenting, dimana keluarga hidup dan melakukan kegiatan sehari-hari. Susunan ruang dalem dapat terdiri dari 2 bagian (depanbelakang) pada rumah Kampung dan Limasan serta 3 bagian (depan-tengahbelakang) pada rumah Joglo. Hierarki ruangnya memperlihatkan adanya gradasi berurut dari depan ke belakang. Organisasi ruangnya meng-anut pola closed ended plan, yaitu simetri keseimbangan yang berhenti pada suatu ruang,dalam hal ini senthong tengah, Wiryoprawiro dalam (Supriyanto 2002:12).

\section{Rumah limasan}

Bentuk rumah limasan merupakan perkembangan dari bentuk rumah yang ada sebelumnya. Limasan memiliki daerah empat persegi panjang dan dua buah atap (kejen atau cocor) serta dua atap lainnya (brunjung) yang bentuknya jajaran genjang sama kaki, Ismunandar dalam Budiwiyanto (2009: 6) Cocor berbentuk segitiga sama kaki seperti tutup keong. Karena cenderung untuk berubah, rumah limasan mengalami penambahan pada sisi-sisinya yang disebut empyak emper atau atap emper. Perubahan bentuk tersebut menyebabkan nama dari limasan mempunyai nama masing-masing.

\section{Pandangan hidup masyakarat Jawa}

Pandangan hidup merupakan pedoman bagi suatu bangsa atau masyarakat dalam menjawab atau mengatasi berbagai masalah yang dihadapinya. Di dalamnya terkandung konsep nilai kehidupan yang dicita-citakan oleh suatu masyarakat. Oleh karena itu, pandangan hidup merupakan nilai-nilai yang dianut oleh suatu masyarakat dengan pilihan secara selektif oleh individu, kelompok atau bangsa (Setiadi, dkk: $34)$.

Dalam kaitan dengan rumah Jawa sebagai manifestasi kesatuan makro dan mikrokosmos serta pandangan hidup masyarakatnya, Koentja-raningrat dalam Supriyanto (2002: 11) menyebutkan adanya klafisifi-kasi simbolik berdasarkan 2 kategori berlawanan yang saling melengkapi dan mendukung, yang oleh Tjahjono dalam Supriyanto (2002: 11) disebut dualitas ( duality ). 
Kategori ini membagi rumah menjadi kanan-kiri, luar-dalam, sakral-profan, publik-privat. Lebih jauh Tjahjono dalam Supriyanto (2002: 11) juga menyebutkan adanya centralitas ( centre), yaitu pemusatan atau penya-tuan dalam tata ruang bangunan, dimana senthong merupakan pusat dari dalem, dalem merupakan pusat kesatuan pendopo, pringgitan dan dalem, sedangkan komposisi tersebut me-rupakan pusat keseluruhan komposisi bangunan dalam satu domain halaman.

Kehidupan masyarakat Jawa juga sangat kental dengan aspek sosial budaya Jawa yang khas. Orang Jawa memiliki tata cara dan aturan tersendiri dalam mengatur setiap sikap dan perilaku masyarakat Jawa. Sikap dan perilaku orang Jawa selalu mengajarkan kebaikan dan toleransi. Orang Jawa tidak boleh mempunyai sikap ingin menang sendiri, mempunyai kebiasaan yang menjatuhkan harga diri seperti tradisi lembu peteng (kumpul kebo) dan sebagainya. Sikap yang baik yang selalu diajarkan adalah dunia damai, yaitu cita-cita luhur tentang budaya damai. Kedamaian bagi orang Jawa itu nomor satu (Endraswara, 2010:381). Hal ini mengisyaratkan bahwa sebenarnya kebudayaan Jawa mempunyai nilai yang luhur. Kebudayaan Jawa senantiasa mengajarkan tentang kehidupan yang harmonis dengan cara saling menghargai, menghormati toleransi, kerja sama, menjaga harga diri, dan lain sebagainya (Astuti, 2017).

\section{Norma masyarakat Jawa}

Wisadirana (2004:31), norma merupakan nilai pengatur tingkah laku individu, agar individu berperilaku sesuai dengan yang diharapkan masyarakat. Orang diharapkan dapat bertindak menurut nilai-nilai yang dipegang kepada kelompoknya, dimana ia menjadi anggota kelompok tersebut dan tindakan ini "yang diharapkan" masyarakat yang merupakan perilaku berdasarkan norma.

Berdasarkan pada tujuan norma dan nilai, yaitu untuk kesederhanaan dan kesejahteraan serta kejelasan perilaku, maka norma-norma dibagi menjadi tiga kategori yaitu folkways, adat istiadat, dan hukum (Wisadirana (2004:34).

Folkways atau disebut sebagai kelaziman adalah peraturan tentang perilaku informal berdasarkan pada tradisi dan kebiasaan. Folkways ditemukan pada perilaku 
manusia yang mengikuti berbagai kebiasaan yang dilakukan sejak nenek moyang dan dianggap baik, patut, layak, sopan-santun, serta tata krama. Pada masyarakat Jawa, Koentjaraningrat (1976:322) menyatakan bahwa di dalam pergaulan-pergaulan hidup maupun perhubungan-perhubungan sosial sehari-hari mereka berbahasa Jawa. Pada waktu mengucapkan bahasa daerah ini, seseorang harus memperhatikan dan membeda-bedakan keadaan orang yang diajak berbicara atau yang sedang dibicarakan, berdasarkan usia maupun status sosialnya.

Agama Islam umumnya berkembang baik di kalangan masyarakat orang Jawa. Hal ini tampak nyata pada bangunan-bangunan khusus untuk tempat beribadat orangorang yang beragama Islam. Walaupun demikian tidak semua orang beribadat menurut agama Islam, sehingga berlandasan atas kriteria pemelukan agamanya, ada yang disebut Islam santri dan Islam kejawen. Kecuali itu masih ada juga di desa-desa Jawa orang-orang pemeluk agama Nasrani atau agama besar lainnya (Kuntjoroningrat, 1976: 339). Mores atau tata kelakuan adalah peraturan yang sebagian besar diteruskan dari orang tua pada anak-anak sebagai bagian dari pelatihan mereka. Aturan ini lebih sedikit fleksibel dari pada folkways, karena didukung oleh agama dan akhlak yang religoin-based, dimana mereka berhubungan. Pada masyarakat Jawa biasanya dilakukan selamatan, suatu upacara makan bersama untuk memperoleh keselamatan hidup (Wisadarna, 2004: 34).

Adat istiadat atau custom merupakan tata kelakuan yang kuat dan kekal integrasinya dengan pola perilaku. Seseorang yang melanggar adat istiadat akan dikenai sanksi berbentuk penderitaan (Wisadarna, 2004: 34).

Hukum merupakan peraturan yang bersifat formal, tegas dan eksplisit dalam bentuk tertulis serta berbentuk paksaan. Hukum dianggap memiliki arti penting dan berfungsi perlindungan bagi masyarakat dan penduduk. Hukum adat merupakan aktivitas dalam rangka suatu kebudayaan yang mempunyai fungsi pengawasan sosial, sedangkan yang dimaksud adat adalah aktifitas di dalam rangka kebudayaan yang tidak mempunyai sanksi pengawasan sosial, tapi hanya sebagai bentuk kebudayaan ide (abstrak). Pada masyarakat Jawa, hukum yang diterapkan menganut pada pemerintahan daerah (Wisadarna, 2004: 34). 
Dalam kehidupan sehari-hari masyarakat Jawa sangat menekankan kehidupan rukun damai. Masyarakat harus memegang prinsip kerukunan, di mana hubungan antar sesama berjalan dengan harmonis. Hubungan seperti ini dapat dilihat ketika ada warga yang menyelenggarakan hajatan atau pernikahan. Dalam situasi ini tetangga sekitar rumah hajatan akan berpartisipasi dalam persiapan dan penyelenggarakan acara tersebut dengan membantu memasak dan menata ruangan sebelum acara dimulai. Mereka juga datang untuk memberikan sumbangan saat acara hajatan atau pernikahan tesebut dilangsungkan. Selain itu, toleransi masyarakat Jawa juga bertumbuhkembang. Ketika ada warga yang sedang ditimpa kemalangan atau musibah seperti meninggal dunia, tetangga sekitar dan bahkan warga yang rumahnya jauh ikut datang untuk turut berbelasungkawa saat mendengar kabar berita duka tersebut (Ariyani, 2013).

\section{Prinsip harmonisasi atau keselarasan masyarakat Jawa}

Prinsip kerukunan bertujuan untuk mempertahankan masyarakat dalam keadaan yang harmonis. Keadaan yang semacam itu disebut rukun. Rukun berarti "berada dalam keadaan selaras", "tenang dan tentram", "tanpa perselisihan dan pertentangan", "bersatu dalam maksud untuk saling membantu”. Selanjutnya perlu kita perhatikan dua segi dalam tuntutan kerukunan. Pertama, dalam pandangan Jawa masalahnya bukan penciptaan keadaan keselarasan sosial, melainkan lebih untuk tidak mengganggu keselarasan yang diandalkan sudah ada (Magniz dan Suseno, 2005:39).

Dalam perspektif Jawa ketenangan dan keselarasan sosial merupakan keadaan normal yang akan terdapat dengan sendirinya selama tidak diganggu, seperti juga permukaan laut dengan sendirinya halus kalau tidak diganggu oleh angina atau oleh badan-badan yang menentang arus (Magniz dan Suseno, 2005: 39). Inti prinsip kerukunan ialah tuntutan untuk mencegah segala kelakuan yang bisa menimbulkan konflik terbuka. Tujuan kelakuan rukun ialah keselarasan sosial, keadaan yang rukun (Magniz dan Suseno, 2005: 52). 
Bagi masyarakat Jawa, interaksi antarsesama didasari oleh dua prinsip yang oleh Suseno (2003) yaitu prinsip kerukunan dan prinsip hormat. Kedua prinsip ini merupakan kerangka normative yang menentukan bentuk-bentuk konkret semua interaksi. Apa yang dilakukan masyarakat Sekaran dalam contoh kasus di atas adalah semata-mata untuk mengupayakan kondisi kerukunan, dimana kerangka ideal dari prinsip ini bertujuan untuk mempertahankan masyarakat dalam keadaan yang harmonis. Begitu pula dengan prinsip hormat, maka tindakan-tindakan di atas merupakan bentuk dari bagaimana orang Jawa mampu menempatkan diri dalam berbagai hubungan sosial (Ariyani, 2013).

\section{Prinsip hormat masyarakat Jawa}

Prinsip itu mengatakan bahwa setiap orang dalam cara bicara dan membawa diri selalu harus menunjukkan sikap hormat terhadap orang lain, sesuai dengan derajat dan kedudukannya. "Apabila dua orang bertemu, terutama dua orang Jawa, bahasa, pembawaan dan sikap mereka mesti mengungkapkan suatu pengakuan terhadap kedudukan mereka masing-masing dalam suatu tatanan sosial yang tersusun dengan terperinci dan cia rasa. Mengikuti aturan-aturan tatakrama yang sesuai, dengan mengambil sikap hormata atau kebapaan yang tepat, adalah amat penting (Wilner dalam Magniz dan Suseno, 2005:60)".

Prinsip hormat berdasarkan pendapat, bahwa semua hubungan dalam masyarakat teratur secara hierarkis, bahwa keteraturan hirarkis itu bernilai pada dirinya sendiri dan oleh karena itu orang wajib untuk mempertahankannya dan untuk membawa diri sesuai dengannya (H. Gertz dalam Magniz dan Suseno, 2005:60). Pandangan itu sendiri berdasarkan cita-cita tentang suatu masyarakat yang teratur baik, dimana setiap orang mengenal tempat dan tugasnya dan dengan demikian ikut menjaga agar seluruh masyarakat merupakan suatu kesatuan yang selaras.mereka yang berkedudukan lebih tinggi harus diberi hormat. Sedangkan sikap yang tepat terhadap mereka yang berkedudukan lebih rendah adalah sikap kebapaan atau keibuan dan rasa tanggung jawab (Magniz dan Suseno, 2005:60). 


\section{Dimensi fisik masyarakat Jawa}

Rumah merupakan bagian kebudayaan fisik, yang dalam konteks tradisional merupakan bentuk ungkapan yang berkaitan erat dengan kepribadian masyarakat. Ungkapan fisiknya sangat dipengaruhi faktor sosio-kultural masyarakat setempat. Perbedaan wilayah dan latar budaya akan menyebabkan perbedaan pula dalam ungkapan arsitektur bangunannya (Magniz dan Suseno, 2005:60).

\section{Dimensi metafisik masyarakat Jawa}

Transendensi adalah dasar eksistensi, sebab eksistensi tidak mempunyai dasar dalam dirinya sendiri. Baru karena hubungannya dengan Transendensi maka manusia menjadi eksistensi yang sungguh-sungguh; eksistensi baru mendapatkan kesadaran sebenarnya tentang keterbatasannya dalam Transendensi (Anas, 2013: 36).

Walaupun Transendensi seolah-olah berbicara melalui dunia tetapi Transendensi tidak dapat dibatasi oleh kategori-kategori, tidak pula hadir sebagai realitas empiris. Pengalaman eksistensial tentang Transendensi tidak dapat dirumuskan dengan memuaskan, karena Transendensi itu merupakan realitas yang tidak terberikan, tidak dapat dikenal. Oleh kerena itu kita tidak sanggup memikirkan Transendensi secara objektif (sebagai objek), maka manusia hanya dapat berbicara tentang pengalaman Transendensi secara simbolis (Anas, 2013: 36).

Jaspers dalam Anas (2013: 37) berpendapat bahwa metafisika mempunyai tempat yang istimewa karena metafisika merupakan sistem spekulatif yang menjawab pertanyaan-pertanyaan paling dalam tentang Allah, manusia dan dunia, itu kini tidak mungkin lagi. Yang masih mungkin dipertanyakan dalam problem metafisika sebagai "jalan mistik dalam pemikiran". Metafisika yang "membaca" seluruh kenyataan sebagai buku yang ditulis Allah, dan yang hanya terdiri dari simbol-simbol.

\section{Tinjauan Pustaka}

Beberapa penelitian terkait rumah limas yang pertama ditulis oleh Dina Sri Nindiati dan Muhammad Idris (2013) yang berjudul "nilai budaya rumah limas 
Palembang sebagai sumber karakter pembelajaran sejarah kebudayaan Indonesia” dalam penelitian ini ditemukan bahwa rumah limas palembang memiliki kekayaan nilai sejarah dan budaya dari lapisan kebudayaan Austronesia, Sinic, Indic, Arab dan Eropa. Nilai karakter yang dapat diangkat dari rumah limas antara lain: karakter toleransi budaya, karakter menghargai karya seni/keindahan, karakter mencintai sejarah dan budaya lokal, karakter religius.

Penelitian kedua dilakukan oleh Yudi Pratama (2019) yang berjudul " rumah limas: refleksi sejarah akulturasi kebudayaan masyarakat sumatera selatan” dalam penelitian ini ditemukan bahwa arsitektur rumah limas mencerminkan sebuah ekspresi kebudayaan yang mengedepankan harmoni sosial serta membentuk kebersamaan. Rumah limas sendiri termauk benda hasil budaya manusia yang mempunyai nilai tersendiri tterutama bagi sejarah dan kebudayaan Sumatera Selatan. Misalnya dalam penyusunan konstruksi dari bahan dasar kayu yang menciptakan nilai dasar seni pada interior.

\section{Metode Penelitian}

Pendekatan penelitian ini adalah kualitatif deskriptif. Pada langkah awal peneliti mengumpulkan data-data pada suatu latar alamiah. Latar alamiah yang dimaksud di sini adalah peneliti mengamati rumah limas Jawa. Teknik yang digunakan dalam penelitin ini adalah observasi. Peneliti mengamati secara langsung rumah limas Jawa. Penelitian kualitatif adalah suatu pendekatan yang juga disebut pendekatan investigasi karena biasanya peneliti mengumpulkan data dengan cara bertatap muka langsung dan berinteraksi dengan orang-orang di tempat penelitian (MC Millan dan Schumacher dalam Syamsuddin Ar dan Vismaia S. Damaianti, 2011: 73). Penelitian kualitatif juga bisa dimaksudkan sebagai jenis penelitian yang temuan-temuannya tidak diperoleh melalui prosedur statistik atau bentuk hitungan lainnya (Strauss dan Corbin, 2007: 4). 


\section{Pembahasan}

\section{Bangunan rumah adat Limasan berdasarkan pandangan hidup masyarakat Jawa}

Pandangan hidup masyarakat Jawa berdasarkan kepercayaannya terlihat dari bangunan rumah Jawa di daerah Yogyakarta dan Surakarta yang dekat dengan Keraton bahwa bangunan rumahnya menghadap ke selatan beradasarkan letak Ratu Nyai Roro Kidul. Meskipun tidak semua rumah adat Jawa menghadap ke selatan karena pergeseran budaya atau karena sudah tidak percaya dengan pandangan hidup tersebut.

Berdasarkan kategori dualitas dan centralitas bangunan rumah Jawa. Kategori dualitas terdiri dari luar dan dalam, antara kiri dan kanan, antara daerah istirahat dan daerah aktivitas, antara spirit laki-laki (tempat placenta yang biasanya diletakkan sebelah kanan) dan spirit wanita (tempat placenta yang biasanya diletakkan pada bagian kiri), sentong kanan dan sentong kiri. Kategori centralitas pada bangunan rumah limasan terletak pada bagian rumah dalem yang terdiri dari emper dan bagian tengah. Bagian rumah tersebut memusat, emper memusat pada ruang tengah.

Hari ini rumah-rumah di Jawa tidak berkolong lagi, tetapi ditempatkan di atas tanah yang sedikit ditinggikan dari permukaan. Ada banyak gaya atap di rumah Jawa sekarang, limasan salah satunya. Urutan arsitektur rumah pun beragam yang terdiri dari beberapa unsur. Pertama pendhapa (di India mandapa). Ini adalah bagian depan rumah Jawa yang terbuka dengan empat saka guru (tiang utama) tempat tuan rumah bertemu dengan tamu-tamunya atau disebut juga ruang pertemuan. Kedua Pringgitan. Ini adalah ruang antara pendhapa dan dalem sebagai tempat untuk pertunjukan wayang (ringgit), yaitu pertunjukan yang berhubungan dengan upacara ruwatan untuk anak sukerta (anak yang menjadi mangsa Bathara Kala, dewa raksasa yang maha hebat). Ketiga Dalem. Ini adalah ruang keluarga; di dalam dalem terdapat senthong atau kamar yaitu: - Senthong tengah atau krobongan atau petanen tempat untuk menyimpan pusaka dan tempat pemujaan Dewi Sri. - Senthong kiwa dan senthong tengen yang berfungsi sebagai ruang tidur. Terakhir Gandhok. Ini adalah 
kamar-kamar yang memanjang yang ada di sebelah kiri dan kanan pringgitan dan dalem. Pawon atau dapur letakya dibelakang senthong (Widayat, 2004).

\section{Bangunan rumah adat Limasan berdasarkan norma masyarakat Jawa}

Berdasarkan norma agama yang dianut masyarakat Jawa bangunan rumah limasan lebih mirip dengan bangunan agama hindhu, meskipun tidak semua masyarakat Jawa memeluk agama Hindhu dan Budha. Hal tersebut berdasarkan asalusul terbentuknya rumah Jawa yang diawali dengan desain dindingnya terbuat dari batu-batu yang disusun seperti bentuk candi. Tetapi bukan berarti bentuk bangunannya berupa candi atau mirip candi.

Berdasarkan folkways yang dianut masyarakat Jawa yang memiliki sopansantun bangunan rumahnya disesuaikan dengan sopan - santun yang biasa dilakukan masyarakat. Sopan-santu tersebut dapat dihubungkan dengan prinsip hormat (menciptakan kedamaian). Bagian depan rumah limasan yang disebut emper dibuat lebih rendah dengan tujuan supaya orang yang bertamu memiliki sopan-santu terhadap tuan rumah.

Berdasrkan norma adat bangunan rumah limasan memiliki bentuk yang sama meskipun dari atap yang selama ini dibuat memiliki beberapa jenis limasan. Adat masyarakat Jawa yang sudah pasti dan apabila dilanggar akan mendapatkan sanksi menjadikan rumah limasan sebagai rumah adat masyarakat Jawa pada zaman kerajaan.

Berdasarkan norma hukum masyarakat Jawa jenis limasan yang dibuat untuk tiap daerah disesuaikan dengan peraturan daerah masing-masing. Berdasarkan hal itu muncul beberapa jenis limasan dan yang membedakannya adalah bentuk atapnya.

\section{Bangunan rumah adat Limasan berdasarkan prinsip harmonisasi masyarakat Jawa}

Bentuk bangunan rumah limasan memiliki nilai harmonisasi yang sangat kuat. Bentuk bangunan yang sederhana dan memiliki kemiripan antara rumah satu dengan yang lain merupakan simbol bahwa masyarakat Jawa menjunjung tinggi nilai 
harmonisasi. Masyarakat Jawa memiliki pandangan bahwa hidup harmonis dalam masyarakat adalah yang utama, meskipun bertentangan dengan hati nuraninya. Bentuk bangunan yang sama antara satu rumah dengan rumah lainnya bertujuan untuk menghindari rasa iri antar masyarakat Jawa.

Pengertian antara wilayah dalam dan luar, antara keterbukaan bermasyarakat dan keintiman tertutup keluarga di sini memperoleh kesatuan yang harmonis, sehingga bukan pertentangan melainkan dialektika luar-dalam antara hidup pribadi dan kemasyarakatan tercapai sangat seimbang. Begitu pula penataan dalem yang sakral dan pendapa yang profan menunjukkan betapa serasi dialektik antara hubungan-hubungan vertikal ke Tuhan dengan yang immanen, yang mengatasi dengan yang mendalami.

\section{Bangunan rumah adat Limasan berdasarkan prinsip hormat masyarakat Jawa}

Pembangunan rumah Limasan didasarkan pada prinsip hormat masyarakat Jawa yang ditunjukkan dari bentuk depan bagian rumah yang biasa disebut emper. Emper dalam rumah limasan dibuat lebih rendah dari bangunan pertama dari rumah limasan. Tujuan dari pembangunan emper yang lebih pendek tersebut supaya orang yang akan masuk ke dalam rumah menunduk dan menghormati tuan rumah.

Banguan emper tersebut yang paling menunjukkan bahwa masyarakat Jawa menjunjung tinggi rasa hormat terhadap sesama. Masyarakat Jawa memiliki rasa hormat meskipun orang yang dihormati itu tidak dikenal. Orang yang biasanya dihormati adalah orang yang lebih tua dan yang memiliki kedudukan lebih tinggi.

\section{Bangunan rumah adat limasan berdasarkan dimensi fisik masyarakat Jawa}

Dimensi fisik berhubungan dengan soio-kultural masyarakat Jawa. Bangunan rumah limasan memiliki desain arsitektur sesuai dengan keadaan masyarakat Jawa. Kepribadian masyarakat yang sederhana terlihat jelas dari bangunan rumah limasan. Seperti yang telah dijelaskan sebelumnya bahwa prinsip harmonisasi bangunan rumah Jawa menunjukkan bahwa bangunannya sederhana. Prinsip tersebut merupakan cerminan fisik masyarakat Jawa yang menyukai kesederhanaan. 


\section{Bangunan rumah limasan berdasarkan dimensi metafisik masyarakat Jawa}

Dimensi metafisika dalam rumah limasan dihubungkan berdasarkan bagianbagian rumah yang memiliki nilai mistik. Nilai mistik tersebut dipengaruhi oleh agama dan kepercayaan masyarakat Jawa. Setiap bagian rumah memiliki nilai metafisik yang dipercaya sebagai makna yang sesungguhnya dari bagian ruangan rumah limasan.

\section{Kesimpulan}

Dari pembahasan di atas dapat disimpulkan bahwa arsitektur rumah Limasan erat kaitannya dengan prinsip hormat masyarakat Jawa yang ditunjukkan dari bentuk depan bagian rumah yang biasa disebut emper. Emper dalam rumah limasan dibuat lebih rendah dari bangunan pertama dari rumah limasan. Tujuan dari pembangunan emper yang lebih pendek tersebut supaya orang yang akan masuk ke dalam rumah menunduk dan menghormati tuan rumah. Banguan emper tersebut yang paling menunjukkan bahwa masyarakat Jawa menjunjung tinggi rasa hormat terhadap sesama. Masyarakat Jawa memiliki rasa hormat meskipun orang yang dihormati itu tidak dikenal. Orang yang biasanya dihormati adalah orang yang lebih tua dan yang memiliki kedudukan lebih tinggi.

Pola bangunan yang seperti ini menandakan bahwa rumah limasan memiliki nilai harmonisasi yang sangat kuat. Bentuk bangunan yang sederhana dan memiliki kemiripan antara rumah satu dengan yang lain merupakan simbol bahwa masyarakat Jawa menjunjung tinggi nilai harmonisasi. Masyarakat Jawa memiliki pandangan bahwa hidup harmonis dalam masyarakat adalah yang utama, meskipun bertentangan dengan hati nuraninya. Bentuk bangunan yang sama antara satu rumah dengan rumah lainnya bertujuan untuk menghindari rasa iri antar masyarakat Jawa. 


\section{REFERENSI}

Adisukma, W. (2013). Makna Pendhapa Ageng Mangkunegaran Sebagai Bangunan Adat Jawa. Brikolase: Jurnal Kajian Teori, Praktik dan Wacana Seni Budaya Rupa, 5(1).

Anas, Mohammad. 2013. Telaah Metafisik Upacara Kasada, Mitos dan Kearifan Hidup Dalam Masyarakat Tengger. Kalam, Jurnal Studi Agama dan Pemikiran Islam, Vol. 7 No. 1, hal 21-52.

Ariyani, N. I. (2013). Strategi adaptasi orang Minang terhadap bahasa, makanan, dan norma masyarakat Jawa. Komunitas: International Journal of Indonesian Society and Culture, 5(1).

Astuti, C. W. (2017). Sikap Hidup Masyarakat Jawa dalam Cerpen-Cerpen Karya Kuntowijoyo. Jurnal Kata: Penelitian tentang Ilmu Bahasa dan Sastra, 1(1), 6471.

Budiwiyanto, Joko. 2009. Penerapan Unsur-unsur Arsitektur Tradisional Jawa Pada Interior Public Space di Surakarta.. Gelar, Jurnal Seni Budaya, vol. 7 no.1, hal 120.

Cahyandari, G. O. I. (2017). Tata Ruang dan Elemen Arsitektur pada rumah jawa di Yogyakarta sebagai wujud kategori pola aktivitas dalam rumah tangga.

Cahyono, U. J., Setioko, B., \& Murtini, T. W. (2017). Transformation of form in the growth of modern Javanese house in Laweyan Surakarta. Journal of Architecture and Urbanism, 41(4), 288-295.

Dina Sri Nindiati dan Muhammad Idris. 2013. Nilai Budaya Rumah Limas Palembang Sebagai Sumber Karakter dalam Pembelajaran Sejarah Kebuyaan Islam. Prosiding seminar pendidikan nasional universitas PGRI Palembang, hal 782-798.

Djono, D., Utomo, T. P., \& Subiyantoro, S. (2012). Nilai Kearifan Lokal Rumah Tradisional Jawa. Jurnal Humaniora, 24(3), 269-278.

Ju, S. R., Do, Y. K., \& Santosa, R. B. (2018). Dualism in the Javanese House and Transformation With focus on the houses of Kotagede, Yogyakarta. Journal of Asian Architecture and Building Engineering, 17(1), 71-78. 
Kartono, J Lukito. 2005. Dimensi Arsitektur. Konsep Ruang Tradisional Jawa Dalam Konteks Budaya. Dimensi Interior, Vol. 3 No. 22, hal 124-136.

Keeler, W. (1983). Symbolic dimensions of the Javanese house (Vol. 29). Monash Asia Inst.

Kim, D. Y., Oh, H. K., \& Ju, S. R. (2013). A Study on the Belief and the Architecture of Traditional Javanese House. Korean Institute of Interior Design Journal, 22(6), 199211.

Koentjaraningrat. 1976. Manusia dan Kebudayaan. Jakarta: Djambatan.

Magniz, Franz dan Suseno. 2005. Etika Jawa. Jakarta: Gramedia.

Michael Quinn Patton. 2009. Metode Evaluasi Kualitatif. Yogyakarta. Pustaka Pelajar.

Musman, A. (2017). Filosofi Rumah Jawa. Anak Hebat Indonesia.

Rianingrum, C. J., Sachari, A., \& Santosa, I. (2015). Representation Of Harmony In Javanese Culture In Building Design Of Kauman Yogyakarta. GSTF Journal of Engineering Technology (JET), 3(2), 58.

Santosa, R. B. (2000). Omah: membaca makna rumah Jawa. Yayasan Bentang Budaya.

Sari, D. P., \& Chiou, Y. S. (2019, August). Transformation in architecture and spatial organization at Javanese house. In 2019 IEEE/ACM International Conference on Advances in Social Networks Analysis and Mining (ASONAM) (pp. 570-577). IEEE.

Setiadi, Elly M, dkk. 2014. Ilmu Sosial Budaya Dasar. Jakarta: Prenada Media Group.

Strauss, Anselm dan Corbin, Juliet. 2009. Dasar-Dasar Penelitian Kualitatif. Yogyakarta: Pustaka Pelajar.

Subiyantoro, S. (2011). Rumah tradisional joglo dalam estetika tradisi jawa. Bahasa dan Seni: Jurnal Bahasa, Sastra, Seni, dan Pengajarannya, 39(1).

Supriyanto, Iwan. 2002. Rumah Tradisional Osing : Konsep Ruang Dan Bentuk. Dimensi Arsitektur, Vol. 30 No.2, hal 10-20.

Tjahjono, G. (1991). Cosmos, center, and duality in Javanese architectural tradition: The symbolic dimensions of house shapes in Kota Gede and surroundings. Theresia, J. (2013). Studi Tata Ruang Dalam Rumah Adat Kudus. Intra, 1(2). 
Widayat, R. (2004). Krobongan ruang sakral rumah tradisi Jawa. Dimensi Interior, 2(1), $1-21$.

Wisadirana, Darsono. 2004. Sosiologi Pedesaan: Kajian Kultural dan Struktural Masyarakat Pedesaan. Malang: UMM Press.

Wismantara, P. P. (2011). Spiritual Journey Principles in Javanese House: an Interdisciplinary Reading. EL HARAKAH Jurnal Budaya Islam, 13(2), 197-214.

Yudi, Pratama. 2019. Rumah Limas: Refleksi Sejarah Akulturasi Kebudayaan Masyarakat Sumatera Selatan. Jambura History and Culture Journal, vol. 1 no. Tahun 2019, hal. 26-37. 